\title{
ARE THE DETERMINANTS OF YOUNG SME PROFITABILITY DIFFERENT? EMPIRICAL EVIDENCE USING DYNAMIC ESTIMATORS
}

\author{
Paulo Maçãs Nunes ${ }^{1}$, Ana Viveiros ${ }^{2}$, Zélia Serrasqueiro ${ }^{3}$ \\ ${ }^{1,3}$ Beira Interior University and CEFAGE Research Center, Universidade da Beira Interior, \\ Estrada do Sineiro, Ernesto Cruz-Polo IV, 6200-209 Covilhã, Portugal \\ ${ }^{2}$ Universidade da Beira Interior and Banco BPI (Banco Português de Investimento) \\ E-mails: ${ }^{1}$ macas@ubi.pt (correspondingauthor); ${ }^{2}$ ana.catarina.viveiros@bancobpi.pt; \\ 3 zelia@ubi.pt
}

Received 01 February 2011; accepted 19 May 2011

\begin{abstract}
Using two step method, namely probit regressions and dynamic estimators, and on the basis of two sub-samples of Portuguese SMEs: 1) 495 young SMEs; and 2) 1350 old SMEs, this study seeks to verify if age is a important factor of the relationships between determinants and profitability. Age, size, liquidity and long-term debt are of greater relative importance for the increased profitability, while risk is of greater relative importance for diminished profitability of young SMEs, compared to the case of old SMEs. R\&D expenditure is of greater relative importance for increased profitability in old SMEs. Additionally, old SMEs have more persistent profitability than do young SMEs.
\end{abstract}

Keywords: dynamic estimators, panel data models, profitability, SMEs, survival, two-step estimation method.

Reference to this paper should be made as follows: Maçãs Nunes, P.; Viveiros, A.; Serrasqueiro, Z. 2012. Are the determinants of young SME profitability different? Empirical evidence using dynamic estimators, Journal of Business Economics and Management 13(3): 443-470.

JEL Classification: C23, D22, G32, L25.

\section{Introduction}

Various fields of knowledge have concentrated on the study of possible determinants of firm performance. In fact, Industrial Economics, Strategic Management and Accountability and Corporate Finance are research areas that have focused upon the determinants of firm performance.

For example, in the area of Industrial Economics, Bain (1956), Porter (1980), and Slater and Olsen (2002), based on the paradigm of Structure - Conduct - Results (S-C-R), have analyzed the variations of firm performance. The main goal of those authors has been to verify if economies of scale and barriers to firms' entry and exit are important for the persistence of firm performance. In addition to the study of the persistence of 
the firm performance, those authors have concentrated their research on the influence of size on firm performance.

In the field of Strategic Management, the main focus of the research has been the analysis of the influence of the organizational structure and management of internal resources on firm performance. Teece (1981), Peteraf (1993), Levinthal (1995), Barney (2001), Moreno et al. (2010), Travkina and Tvaronaviciene (2011), and Moreno and Castillo (2011) have analyzed the influence of several determinants factors as organizational structure, risk, asset structure and size on firm performance.

Finally, in the research field of Accountability and Corporate Finance, several studies (Jensen, Meckling 1976; Myers 1977; Stulz 1990; Callen et al. 1993; Chan et al. 2003) have studied the influence of capital structure on firm performance. In the context of the research field of Accountability and Corporate Finance, the study of the influence of debt and liquidity on firm performance is particularly important.

One of the most frequently used measures of firm performance is profitability. In this study, just as Adams and Buckle (2003), Amato, L. and Amato, C. (2004), Goddard et al. (2005), Gschwandtner (2005), Galbreath and Galvin (2008), and Maçãs Nunes et al. (2010), we use firm profitability, given by the ratio of operational results to assets, as a measure performance. As explanatory variables of profitability, just as Maçãs Nunes et al. (2010), we consider: 1) Age; 2) Expenditure on Research and Development (R\&D); 3) Size; 4) Liquidity; 5) Long-term Debt; and 6) Risk.

The various studies about determinants of profitability (Adams, Buckle 2003; Amato, L., Amato, C. 2004; Goddard et al. 2005; Gschwandtner 2005; Galbreath, Galvin 2008; Serrasqueiro, Maçãs Nunes 2008; Maçãs Nunes et al. 2009; Maçãs Nunes et al. 2010) have neglected the study of the influence of firm age on the relationships between determinants and profitability.

This study seeks to verify if SME age is a determinant factor of the relationships between determinants and profitability. Considering that SMEs are much more vulnerable and sensitive to macroeconomic changes, economic downturns, and also to the competition within the market, it is important to study: 1) the determinants that may stimulate SME profitability and those that may restrict profitability; and 2) given the importance of young SMEs in stimulating the employment and economic growth, it is worth to verify if age of SMEs is an important factor that may contribute to important differences between the factors promoting and the factors restraining the firm profitability.

In Portugal, SMEs represent around 99.6\% of businesses (IAPMEI 2008) and are crucial for stimulating the country's employment and economic growth. The importance of SMEs in the context of industrial activity in Portugal justifies the study of the influence of age on the determinants of profitability of Portuguese SMEs. Additionally, this study seeks to understand if governmental policies that promote the sustainability of SME profitability should be of a different nature, according to the subject of analysis being young or old SMEs.

Methodologically, we consider a panel made up of 1845 Portuguese SMEs for the period 1999-2006. We consider as young SMEs those firms those of up to 10 years of age in 2006, considering the remainder of SMEs included in the database as old SMEs. 
We use the two-step estimation method proposed by Heckman (1979), so as to address the problem of possible bias of estimated results, as a consequence of the matter of survival. In a first step, we estimate probit regressions for young and old SMEs with all surviving and non-surviving SMEs. In a second step, based on the previously estimated probit regressions, we calculate the inverse Mill's ratio and add it as an explanatory variable of profitability in young and old SMEs. In this second step, we use dynamic panel estimators, namely GMM (1991), GMM system (1998) and LSDVC (2005) estimators. It should be noted that in the second step of estimation, just as Heckman (1979), we only consider the surviving SMEs. Use of dynamic panel estimators, just as in Gschwandtner (2005) and Maçãs Nunes et al. (2009), allows us to determine the persistence of profitability in young and old SMEs, i.e. we analyze the relationship between profitability in the current period and in the previous period for young and old SME, also checking whether age is a fundamental characteristic of the magnitude of profitability persistence.

The empirical evidence obtained allows us make the following contribution to the literature: age is a determinant factor of the relationships between determinants and profitability. More specifically, we ascertain that: 1) age, liquidity, and long-term debt influence positively the young SMEs profitability; but age influences negatively the old SME profitability, and liquidity and long-term debt do not influence the old SMEs profitability; 2) size influences positively the young and old SME profitability, but the positive influence is greater for young SMEs than for old SMEs; 3) risk influences negatively the young SME profitability, but it does not influence the old SMEs profitability; 4) R\&D expenditure influence positively the old SME profitability, but do not influence the young SME profitability; and 5) persistence of profitability is greater for old SMEs than for young SMEs. In addition, use of the two-step estimation method allows an additional contribution of the current study: significant differences are found between the determinants of young and old SME survival.

After this introduction, the study is structured as follows: 1) Section 2 presents the literature review and research hypotheses; 2) Section 3 presents the database, variables and the estimation method used; 3) Section 4 presents the results obtained; 4) Section 5 goes on to discuss the results; and 5) finally, Section 6 presents the conclusions and implications of the study.

\section{Literature review and investigation hypotheses}

\subsection{Age}

There is no consensus on the influence of age on firm performance. On the one hand, Jovanovic (1982) concludes that the firm's owners and/or managers need to take time to understand their real business possibilities. According to Jovanovic (1982), only as the years pass, firm owners and/or managers become more efficient in the selection of the investment opportunities. Based on this argument, Jovanovic (1982) concludes that the firms in the more advanced stages of their life-cycle are more able to obtain higher rates of financial performance. 
Younger firms are normally more proactive and have a greater perception of the risk of the various investment alternatives that arise (Lumpkin, Dess 1996; Lumpkin 1998; Shane, Venkataraman 2000). Additionally, younger firms are more efficient in selecting the most profitable investments, compared to what occurs in firms in more advanced stages of their life-cycle, given that young firms are particularly concentrated on their survival (Lumpkin, Dess 1996; Lumpkin 1998; Shane, Venkataraman 2000). Lumpkin and Dess (1996), Lumpkin (1998), and Shane and Venkataraman (2000) conclude that it is expectable that young SMEs have higher levels of profitability than do old SMEs.

SMEs are associated with considerable business risk compared to the case of large firms. In the first years of SME life cycle, high business risk associated with possible difficulty in obtaining credit can lead SMEs being unable to take advantage of the investment opportunities that arise. In addition, Jovanovic (1982) concludes that firms in the first years of their life-cycle have the main concern of reaching the minimum scale of efficiency that allows them to survive. Given that SMEs are particularly exposed to risk and to the effects of competition, the smaller size of SMEs, compared to large firms, implies greater relative importance of the need to obtain the minimum scale of efficiency that allows survival.

Based on the arguments above, we formulate the following hypothesis:

H1: Age is of greater relative importance for increased profitability in young SMEs than for increased profitability in old SMEs.

\subsection{Other determinants}

\subsubsection{Research and development}

Andries and Debackere (2007) conclude that expenditure on Research and Development is fundamental for an increased propensity of firms for innovation. According to Andries and Debackere (2007), SMEs with more intensive expenditure on Research and Development have a greater innovative capacity, and, consequently more strategic flexibility to diversify their investments, which may contribute decisively to increasing their levels of profitability.

The benefits of SME investment in Research and Development are also stated by other authors. Rogers (2004) concludes that SMEs with higher investment in Research and Development have greater organizational flexibility which may contribute to a greater efficiency in implementing the growth opportunities. Taking greater advantage of growth opportunities can mean increased SME profitability. Beise-Zee and Rammer (2006) claim that diversification of activities, as a consequence of SMEs' greater investment in Research and Development, can mean greater export capacity. Less risk in SME activity, as a consequence of greater export capacity, may contribute to increased profitability. Finally, according to Rickne (2006), SMEs that invest more in Research and Development have a greater propensity to be involved in cooperation networks with other SMEs. Cooperation networks can contribute to a greater diversification of SME activities, which can contribute to increasing levels of profitability (Rickne 2006).

However, investment in Research and Development may contribute to diminished SME profitability, since: 1) investment in Research and Development contains quite a high 
risk, which together with the high risk associated with SME activities in general, can lead to difficulties in managing financial resources, when internal financing is insufficient (Yasuda 2005; Müller, Zimmermann 2009); 2) if SMEs do not have an extended learning period in managing Research and Development investment, this can imply inefficient use of investment opportunities (Müller, Zimmermann 2009); and 3) to finance Research and Development activities, SMEs frequently need to turn to external financing, given that internal financing may be clearly insufficient for this purpose. The strong difficulties of SMEs to obtain external financing can mean problems in managing their financial resources, and taking advantage of growth opportunities (Tanabe, Watanabe 2005; Gomez, Vargas 2009; Müller, Zimmermann 2009).

The youngest SMEs have the main goal of attaining a minimum scale of efficiency that allows them to survive (Jovanovic 1982). Therefore, SME diversification of activities, as a consequence of greater investment in Research and Development, can be fundamental to reach that goal. However, diversification of activities can also be fundamental for the growth and sustainability of old SMEs, since they can stagnate if beyond a certain moment of their life-cycle they do not invest in Research and Development, and consequently they may exhaust their profitable investment opportunities.

The contribution of age to increased SME reputation (Diamond 1989), and diminished probability of bankruptcy (Müller, Zimmermann 2009), may allow old SMEs an easier access to alternative financing sources. When internal financing is insufficient, the access to alternative financing sources can be fundamental for SMEs to finance their Research and Development activities with less difficulty in managing their financial resources, so contributing to increased profitability. Additionally as a consequence of greater age, the effect of acquired experience in managing the innovation processes (Müller, Zimmermann 2009) may contribute to Research and Development investment of old SMEs causing greater increase in profitability, compared to the case in young SMEs.

Based on the arguments above, we formulate the following hypothesis:

H2: Research and Development Expenditure is of greater relative importance for increased profitability in old SMEs than for increased profitability in young SMEs.

\subsubsection{Size}

Various authors (Winter 1994; Hardwick 1997; Wyn 1998; Gschwandtner 2005) state that firm size is fundamental for increased levels of profitability. According to the authors, greater firm size contributes to firms to have: 1) greater ability to take advantage of economies of scale; 2) greater capacity to diversify activities and products; and 3) greater ability to implement strategies seeking to increase the barriers to the entry of potential competitors.

However, other authors (Pi, Timme 1993; Goddard et al. 2005) state that greater firm size can contribute to reduced ability of owners to control managers' actions. Less control of managers' actions by owners can imply investment in projects that increase managers' own prestige, such as projects that make firms grow beyond the desirable size, and which can contribute to diminished firm's profitability. 
In the majority of SMEs, the ownership and management are in the hands of the same individuals, therefore the negative impacts of increased size on profitability can be minimal, and so we can expect that greater SME size contributes to increasing firms' profitability levels.

However, we can expect that the size of young SMEs to be more relevant for increasing young SME profitability, compared to the case of old SMEs. Since young SMEs in general can be far from the minimum size that allows survival (Jovanovic 1982; Lotti et al. 2009), then the greater size can have greater relative importance for young SMEs to have: 1) greater ability to take advantage of economies of scale; 2) greater capacity to diversify activities and products; and 3) greater capacity to raise barriers to the entry of potential competitors, compared to the case of old SMEs.

Based on the above arguments, we formulate the following hypothesis:

H3: Size is of greater relative importance for increased profitability in young SMEs than for increased profitability in old SMEs.

\subsubsection{Liquidity}

Fama and Jensen (1983) and Myers and Rajan (1995) conclude that when firms have excessive liquidity, managers can invest in projects that maximize their own personal benefits, but reducing firm's profitability. However, Ang (1991) concludes that the negative effects of excessive liquidity on SME profitability are minimal as a consequence of SME ownership and management, in most cases, being concentrated in the same individuals.

Higher liquidity levels mean a greater possibility for firms to be more effective in facing up the potential changes of their operating markets as a consequence of increased competition (Goddard et al. 2005). This occurs because firms with higher levels of liquidity are more able to respond to increased competition, as a consequence of the lesser stress in managing their financial resources.

Higher levels of liquidity can be particularly relevant for SME to make efficient use of the various investment opportunities that arise, contributing to increased profitability (Honjo, Harada 2006). Deloof (2003) concludes that the importance of SME liquidity for increased SME profitability can arise from the great possibility of firm's accomplishment of short-term commitments, as well as from the greater efficiency in managing financial resources to take advantage of good investment opportunities. Fagiolo and Luzzi (2006) reinforce the conclusions of Deloof (2003), claiming that the information asymmetry inherent in the relationship between SME owners and creditors can cause an excessive dependence of SMEs on short-term debt, which may generate financial stress, due to the need to pay debt and its charges over a very short period of time.

The youngest SMEs have greater difficulty in accessing external financing than old SMEs. Indeed, the lesser reputation of young SMEs (Diamond 1989) and the greater possibility of bankruptcy (Müller, Zimmermann 2009) contribute to greater difficulties of young SMEs in obtaining external financing on advantageous terms, compared to the case of old SMEs. For example, creditors can grant more short-term debt, and less 
long-term debt, so as to monitor more easily the repayment of the debt and charges by SMEs. In this context, Serrasqueiro and Maçãs Nunes (2010) conclude that when internal finance is insufficient, young SMEs are excessively dependent on short-term debt, whereas old SMEs are more able to obtain long-term debt. This being so, we can expect that liquidity to be particularly important for increased profitability in young SMEs.

Based on the arguments above, we formulate the following hypothesis:

H4: Liquidity is of greater relative importance for increased profitability in young SMEs than for increased profitability in old SMEs.

\subsubsection{Long-term debt}

Jensen and Meckling (1976) conclude that firm owners/managers may prefer debt to the finance highly profitable projects, but which may also contain a high level of risk. When the projects are successful, the firm's owners/managers are the main beneficiaries. On the contrary, in the case of failure of the projects, the creditors bear almost all the costs. Myers (1977) concludes that creditors hinder the granting of long-term debt to firms, when the projects to be financed imply a high level of risk. In situations of high risk associated with investment projects, Myers (1977) concludes that creditors prefer to grant short-term debt so as to monitor the repayment of the debt and its charges more easily.

Fagiolo and Luzzi (2006) conclude that when internal financing is insufficient, debt can be fundamental SMEs, so that these firms can finance all good investment opportunities that arise. Nevertheless, the authors conclude that the excessive dependence on shortterm debt of SMEs, when internal financing is insufficient, can contribute to reduce the liquidity, which will lead to excessive stress in managing financial resources, and which in turn may imply less efficient use of the good investment opportunities.

For Fagiolo and Luzzi (2006), when internal financing is insufficient, if SMEs have greater access to long-term debt, this can contribute to increased SME profitability. According to these authors, this occurs because SMEs can manage their financial resources with less stress, which can be fundamental for taking advantage of all good investment opportunities that arise.

Serrasqueiro and Maçãs Nunes (2010) conclude that when internal financing is insufficient, young SMEs are excessively dependent on short-term debt, whereas old SMEs, in the same circumstances, are more able to obtain long-term debt. The greater reputation acquired with greater SME age (Diamond 1989), as well as the lesser possibility of bankruptcy of older SMEs (Müller, Zimmermann 2009), may be determinant factors for older SMEs having easier access to long-term debt.

When internal financing is insufficient, SMEs' excessive dependence on short-term debt and consequent financial stress in managing their financial resources can lead to a greater importance of long-term debt to increased profitability.

Based on the arguments above, we formulate the following hypothesis:

H5: Long-term debt is of greater relative importance for increased profitability in young SMEs than for increased profitability in old SMEs. 


\subsubsection{Risk}

Various authors (Fama, Jensen 1983; Titman, Wessels 1988; Lamm-Tennant, Starks 1993; Adams, Buckle 2003) state that firms, with high volatile operational results, are more exposed to situations of risk.

Pettit and Singer (1985) conclude that SMEs with high operational risk have considerable difficulty in obtaining debt. In fact, it is sometimes difficult for creditors to assess the exact nature of SME assets, since the great flexibility of SMEs' organizational structure can lead to considerable changes in the composition of their assets. Additionally, in highrisk situations, SME owners/managers can begin investing in projects that maximize their benefits, and cease to invest in projects that contribute to firm increased profitability.

From the above, we can expect that greater operational risk of SMEs implies diminished levels of profitability. However, the majority of SMEs in the beginning of their life-cycle have not yet reached the minimum scale of efficiency that allows them to survive in their operating markets (Jovanovic 1982). Consequently, those SMEs are more exposed to a higher risk, and we can expect a more accentuated reduction in the profitability of this type of SME, compared to the case of SMEs in the later stages of their life-cycle.

Based on the reasoning set out, we formulate the following hypothesis:

H6: Risk is of greater relative importance for diminished profitability in young SMEs than for diminished profitability in old SMEs.

\subsubsection{Profitability in the previous period}

According to Mueller (1986), there is a propensity of firm profitability persistence over time, i.e., a statistically significant relationship between firm profitability in the previous period and firm profitability in the present period. That author argues that this occurs because the possible small divergences between profitability in the previous and present periods are immediately cancelled out by the entry and exit of firms in the market.

In the context of persistence of firm profitability, the conclusions of Gschwandtner (2005) are quite relevant. The author concludes that the greater level of risk associated with firm's activities, and the consequently greater likelihood of bankruptcy, contribute to diminished persistence of profitability.

Young SMEs have less persistent profitability than old SMEs, because the former are more risky, and consequently have greater likelihood of bankruptcy, compared to the case of old SMEs.

Based on this reasoning, we formulate the following hypothesis:

H7: Persistence of profitability is greater in old SMEs than in young SMEs.

\section{Methodology}

\subsection{Database}

This study uses the SABI (Sistema de Balanços Ibéricos - System Analysis of Iberian Balance Sheets) database supplied by Bureau van Dijk, for the period between 1999 and 2006. We select SMEs on the basis of the European Union's recommendation L124/36 
(2003/361/CE). According to this recommendation, a firm is considered to be an SME, when it meets two of the following criteria: 1) fewer than 250 employees; 2) total assets under 43 million euros; 3 ) business turnover under 50 million euros.

According to Arellano and Bond (1991), use of dynamic panel estimators implies that cross-sections are included in the database for at least four consecutive years, so as to be considered in the econometric analysis, namely in the second-order autocorrelation tests. These tests are fundamental to confirm the robustness of the empirical results obtained. Given that dynamic panel estimators are used in this study, we eliminate firms that do not belong to the database for at least four consecutive years in the period 1999-2006.

Seeking to address the problem of possible bias in the results, and to have a more representative database of the actual structure of Portuguese SMEs, we consider three types of SMEs: 1) SMEs that remain in the market for the whole period of analysis; 2) SMEs that enter in the market during the period of analysis; and 3) SMEs that leave the market during the period of analysis.

Given that our study's goal is to study the influence of age on the profitability of Portuguese SMEs, we consider two research sub-samples: 1) 495 young SMEs: 236 of which enter the market during the period of analysis, and 36 of them leave the market during that time; and 2) 1350 old SMEs: 162 of which leave the market during the period of analysis. We consider as young SMEs those in existence up to a maximum of 10 years in the end of the analysis period ${ }^{1}$, considering as old SMEs all those over 10 years old in the end of the analysis period ${ }^{2}$.

Table 1 presents the structure of the database considered in this study.

In order to test the robustness of the empirical evidence obtained, namely if it depends on the criterion of classification used, we consider an alternative classification criterion

Table 1. Description of database

\begin{tabular}{lcccc}
\hline & \multicolumn{2}{c}{ Young SMEs } & \multicolumn{2}{c}{ Old SMEs } \\
\hline & Firms & Observations & Firms & Observations \\
\hline $\begin{array}{l}\text { Firms Present for the Whole } \\
\text { Period 1999-2006 }\end{array}$ & 223 & 1561 & 1188 & 8316 \\
\hline $\begin{array}{l}\text { Firms Entering the Market } \\
\text { in the Period 1999-2006 }\end{array}$ & 236 & 1228 & 0 & 0 \\
\hline $\begin{array}{l}\text { Firms Leaving the Market } \\
\text { in the Period 1999-2006 }\end{array}$ & 36 & 172 & 162 & 776 \\
\hline Total Number of Firms & 495 & & 1350 & \\
\hline Total Number of Observations & & & & \\
\hline
\end{tabular}

${ }^{1}$ Corresponds to 2006.

${ }^{2}$ Hyytinen and Pajarinen (2004), Oliveira and Fortunato (2006), Ferrando et al. (2007) and La Rocca et al. (2009) consider the same criterion for classifying young and old SMEs. 
for young and old SMEs. According to the alternative criterion, we consider as young SMEs those entering the market in the period 1999-2006, considering the remainder as old $\mathrm{SMEs}^{3}$. In appendix, we present the results.

\subsection{Variables}

The following Table 2 presents the variables used in this study, together with their corresponding measure.

Table 2. Variables and measures

\begin{tabular}{ll}
\hline \multicolumn{1}{c}{ Variables } & \multicolumn{1}{c}{ Measures } \\
\hline Profitability $\left(P R O F_{i, t}\right)$ & $\begin{array}{l}\text { Rependent Variable } \\
\text { Ratio of Operational Profits before Interest } \\
\text { and Tax to Total Assets }\end{array}$ \\
\hline Independent Variables \\
\hline Age $\left(A G E_{i, t}\right)$ & Logarithm of the Number of Years of Firm Existence \\
\hline $\begin{array}{l}\text { Intensity of Expenditure on Research } \\
\text { and Development }\left(R \& D_{i, t}\right)\end{array}$ & $\begin{array}{l}\text { Ratio of Expenditure on Research and Development } \\
\text { to Total Assets }\end{array}$ \\
\hline Size $\left(S I Z E_{i, t}\right)$ & Logarithm of Total Assets \\
\hline Liquidity $\left(L I Q_{i, t}\right)$ & Ratio of Short-term Liabilities to Current Assets \\
\hline Long-term Debt $\left(L L E V_{i, t}\right)$ & $\begin{array}{l}\text { Ratio of Medium and Long-term Liabilities } \\
\text { to Total Assets }\end{array}$ \\
\hline Risk $\left(E V O L_{i, t}\right)$ & $\begin{array}{l}\text { Absolute Value of the Percentage Variation } \\
\text { of Operational Profits before Interest and Tax }\end{array}$ \\
\hline
\end{tabular}

The dependent variable is profitability, given by the ratio of operational results to assets. As independent variables, we consider: age, R\&D expenditure, size, liquidity, long-term debt, and risk.

\subsection{Estimation method}

Studying the determinants of SME profitability without correcting possible sample bias as a consequence of not considering the situation of firms that left the market during the period of analysis could lead to bias in the results obtained, given the omission of the

\footnotetext{
${ }^{3}$ According to the alternative criterion, we consider as young SMEs those up to 7 years old, considering as old SMEs those over 7 years old. Robb and Robinson (2009) consider SMEs to be young up to a maximum of 5 years of age. In this study, use of dynamic estimators, with the consequent need for SMEs to be in the sample for at least four consecutive years to validate the second-order autocorrelation tests, recommends use of an alternative criterion with a higher maximum age for classifying young SMEs. However, the alternative criterion we use is similar to that used by Robb and Robinson (2009) since, by considering as young SMEs those entering in the period 1999-2006, they are no more than 7 years old. The alternative criterion used in this study is also quite similar to the one used by Steffens et al. (2009), these authors classifying as young SMEs those up to 8 years old, classifying as old SMEs those over 8 years old.
} 
firms with survival difficulties. That situation could be different from that one presented by firms with good survival possibilities.

The best way to address this problem is use of the two-step estimation method proposed by Heckman (1979). In the first step, considering all firms, both surviving and non-surviving, we estimate a probit regression, in which the dependent variable has the value of 1 if the firm is in the market, and the value of 0 if it has left the market. As independent variables we consider the profitability determinants used in this study.

In the second step, when estimating the regressions relating to the profitability determinants, we only consider surviving firms, adding the inverse Mill's ratio as another explanatory variable so as to control for possible data bias as a consequence of survival.

The probit regression estimated in the first step allows us to calculate the additional explanatory variable, the inverse Mill's ratio that allows us to control for possible sample bias.

In the first step, the probit regression to estimate can be presented as follows:

$$
\operatorname{Pr}\left(\delta_{i, t}=1\right)=\tau_{0}+\kappa P R O F_{i, t-1}+\sum_{K=1}^{6} \tau_{K} X_{K, i, t}+S_{S}+d_{t}+z_{i, t},
$$

where: $P R O F_{i, t-1}$ is profitability in the previous period; $X_{K, i, t}$ is the vector of the profitability determinants $K$ considered in this study ${ }^{4} ; S_{S}$ are industry sector dummy variables ${ }^{5} ; d_{t}$ are annual dummy variables measuring the impact of changes in the economic situation on the likelihood of bankruptcy; and $z_{i, t}$ is the error.

After determining the inverse Mill's ratio ${ }^{6}$ for each of the observations, we consider it as an additional explanatory variable of profitability.

In the second step, in order to estimate the regressions related to the profitability determinants, we use dynamic panel estimators, namely the GMM (1991), GMM system (1998) and LSDVC (2005) estimators. Using dynamic estimators has the following advantages over traditional panel methods (random effect panel model and fixed effect panel model): 1) greater control of endogeneity; 2) greater control of possible collinearity of explanatory variables; and 3) more effectiveness in controlling effects caused by the absence of important independent variables, for explaining the dependent variable. In addition, use of dynamic estimators allows us to correctly determine, i.e. without result bias, the persistence of profitability in Portuguese SMEs.

\footnotetext{
${ }^{4}$ As mentioned before, we consider as determinants of the profitability of young and old Portuguese SMEs: 1) age; 2) R\&D intensity; 3) size; 4) liquidity; 5) long-term debt; and 6) risk.

${ }^{5}$ We consider sector dummy variables representing the main industry sectors: 1) primary sector (I) which includes agriculture and fishing; 2) secondary sector (II) including manufacturing and construction; and 3) tertiary sector (III) including services and commerce.

${ }^{6}$ The inverse Mill's ratio is the ratio between the cumulative density function and the density function. The designation of inverse Mill's ratio is due to the fact that Mill's ratio considers the inverse of Hazard ratio (also known as force of mortality). For a detailed description of the calculation of the inverse Mill's ratio, see Heckman (1979).
} 
The regressions to estimate using the various dynamic panel estimators are expressed as follows:

$$
\text { PROF }_{i, t}=\beta_{0}+\delta \text { PROF }_{i, t-1}+\sum_{K=1}^{6} \beta_{K} X_{k, i, t}+\beta_{\lambda} \lambda_{i, t}+S_{S}+d_{t}+v_{i}+e_{i, t},
$$

where: $\lambda_{i, t}$ is the inverse Mill's ratio; $v_{i}$ are the non-observable individual effects; and $e_{i, t}$ is the error, which assumes normal distribution.

Estimating equation (2) through traditional panel models, namely through random and fixed effect panel models, we would obtain biased estimates of the parameters estimated, due to the existence of correlation between $v_{i}$ and $P R O F_{i, t-1}$, and between $e_{i, t}$ and $P R O F_{i, t-1}$.

Arellano and Bond (1991) recommend the estimation of equation (2) with the variables in first differences, using the lagged profitability and the determinants at level. By estimating equation (2) in first differences, non-observable individual effects $\left(v_{i}\right)$ are eliminated, so eliminating the correlation between $v_{i}$ and $P R O F_{i, t-1}$. Use of the lags of profitability and lags of the determinants creates orthogonal conditions between $e_{i, t}$ and $P R O F_{i, t-1}$, eliminating their correlation.

However, Blundell and Bond (1998) state that in situations of persistence of the dependent variable, i.e. when high correlation is found between the dependent variable in the previous and current periods, and the number of periods is not particularly high, the GMM (1991) estimator leads to inefficient results because the instruments are weak, leading to bias of the estimated results. This bias is particularly important regarding the estimated parameter measuring the relationship between the dependent variable in the previous and current period. In situations of high persistence of the dependent variable, Blundell and Bond (1998) propose use of an alternative estimator, considering a system of variables at levels in first differences. For the variables at level, the instruments are given in first differences. For the variables in first differences, the instruments are given in levels.

However, the GMM (1991) and GMM system (1998) estimators can only be valid on two conditions: 1) if the restrictions created, a consequence of using instruments, are valid; and 2) if there is no second-order autocorrelation. To test the validity of the restrictions created from use of the instruments, we use the Sargan test in the case of the GMM (1991) estimator, and the Hansen test in the case of the GMM system (1998) estimator. In both cases, the null hypothesis is the validity of the restrictions created by using the instruments used, the alternative hypothesis being non-validity of use of the restrictions created by use of the instruments. We also test for the existence of first and second-order autocorrelation. The null hypothesis indicates the non-existence of first and second-order autocorrelation, the alternative hypothesis indicating the existence of first and second-order autocorrelation. In the case of not rejecting the null hypothesis of validity of the restrictions created by the instruments and non-existence of second-order autocorrelation, we conclude that the results obtained from using the GMM (1991) and GMM system (1998) estimators are robust.

Bruno (2005) concludes that in situations where neither the number of cross-sections nor the number of observations is very high, given the relatively high number of in- 
struments compared to the number of observations, this can cause bias of the results obtained using the GMM (1991) and GMM system (1998) estimators. Considering that the number of cross-sections, and consequently the number of observations, is not very high, mainly regarding young SMEs, this study also uses the estimator by Bruno (2005), Least Squares Dummy Variable Corrected - LSDVC, in order to test the robustness of the results previously obtained using the GMM (1991) and GMM system (1998) dynamic estimators.

In order to test the differences in the relationships between determinants and profitability for young SMEs and old SMEs, we use the Chow test ${ }^{7}$. We test for possible differences for each of the determinants considered in this study, as well as the overall difference for the set of determinants considered. The null hypothesis is that no differences are found in the estimated parameters relating to relationships between determinants and profitability for young SMEs and old SMEs, the alternative hypothesis being existence of difference in the estimated parameters.

\section{Results}

\subsection{Descriptive statistics}

The following Table 3 presents the descriptive statistics of the variables used in this study for the sub-samples of young SMEs and old SMEs.

Table 3. Descriptive statistics

\begin{tabular}{ccccccccccc}
\hline \multicolumn{1}{c}{ Young SMEs } & \multicolumn{1}{c}{ Old SMEs } \\
\hline Variable & $\mathrm{N}$ & Mean & $\begin{array}{c}\text { Stan. } \\
\text { Deviation }\end{array}$ & Min. & Max. & $\mathrm{N}$ & Mean & $\begin{array}{c}\text { Stan. } \\
\text { Deviation }\end{array}$ & Min. & Max. \\
\hline$P F O F_{i, t}$ & 2961 & 0.047 & 0.102 & -1.511 & 0.581 & 9092 & 0.045 & 0.089 & -2.034 & 1.293 \\
\hline$A G E_{i, t}$ & 2961 & 1.674 & 0.316 & 0 & 2.302 & 9092 & 3.107 & 0.524 & 1.791 & 5.096 \\
\hline$R \& D_{i, t}$ & 2961 & 0.0097 & 0.032 & 0 & 0.694 & 9092 & 0.0096 & 0.035 & 0 & 0.665 \\
\hline$S I Z E_{i, t}$ & 2961 & 14.36 & 1.287 & 10.36 & 17.37 & 9092 & 15.15 & 1.211 & 10.62 & 17.69 \\
\hline$L I Q_{i, t}$ & 2961 & 1.489 & 1.561 & 0.027 & 15.46 & 9092 & 1.589 & 1.623 & 0.041 & 30.60 \\
\hline$L L E V_{i, t}$ & 2961 & 0.062 & 0.159 & 0 & 0.771 & 9092 & 0.121 & 0.156 & 0 & 0.820 \\
\hline$E V O L_{i, t}$ & 2961 & 4.039 & 16.84 & 0.0007 & 38.11 & 9092 & 3.003 & 13.09 & 0.00012 & 31.21 \\
\hline
\end{tabular}

Young SMEs have slightly higher average profitability than old SMEs. Additionally, we find some volatility in the profitability of young SMEs and old SMEs, since standard deviations of profitability are above the respective means.

Regarding independent variables, we find that: 1) $R \& D$ expenditure and risk are on average higher in young SMEs than in old SMEs; and 2) age, size, liquidity and longterm debt are on average higher in old SMEs than in young SMEs.

\footnotetext{
${ }^{7}$ We also use the Chow test to test for differences in the determinants of survival for young SMEs and old SMEs.
} 


\subsection{Survival analysis}

The following Table 4 presents the results of the survival analysis for young SMEs and old SMEs.

Table 4. Analysis of survival - Young SMEs and Old SMEs

\begin{tabular}{ccc}
\hline & Dependent Variable: $\operatorname{Pr}\left(\delta_{i, t}=1\right)$ & \\
\hline Independent Variables & Young SMEs & Old SMEs \\
\hline$P F O F_{i, t-1}$ & $0.54838^{* * *}$ & $0.19283^{* * *}$ \\
& $(0.05647)$ & $(0.04774)$ \\
\hline$A G E_{i, t}$ & $0.09765^{* * *}$ & $0.05854 * * *$ \\
& $(0.02765)$ & $(0.01963)$ \\
\hline$R \& D_{i, t}$ & 0.08763 & $0.31838^{* * *}$ \\
& $(0.10432)$ & $(0.09674)$ \\
\hline$S I Z E_{i, t}$ & $0.13389^{* * *}$ & 0.02604 \\
& $(0.02098)$ & $(0.03001)$ \\
\hline$L I Q_{i, t}$ & $0.17829 * * *$ & $0.08637^{* *}$ \\
& $(0.04472)$ & $(0.04289)$ \\
\hline$L L E V_{i, t}$ & $0.23453^{* * *}$ & $0.11454 * *$ \\
& $(0.05845)$ & $(0.05508)$ \\
\hline$E V O L_{i, t}$ & $-0.04673^{* * *}$ & -0.00534 \\
& $(0.01508)$ & $(0.01786)$ \\
\hline Pseudo $R^{2}$ & 0.43002 & 0.39657 \\
\hline Firms & 459 & 1350 \\
\hline Observations & 2961 & 9092 \\
\hline Robst Stan & & \\
\hline
\end{tabular}

Notes: 1. Robust Standard Deviations in parenthesis. $2 . * * *$ statistically significant at $1 \%$ level; and ** statistically significant at 5\% level. 3. Estimations include sector dummy variables, but estimated parameters are not presented in the tables. 4. Estimates include annual dummy variables, but estimated parameters are not presented in the tables

The empirical evidence allows us to conclude that $\left.{ }^{8}: 1\right)$ profitability in the previous period, age, size, liquidity and long-term debt contribute to a greater likelihood of survival, whereas risk contributes to a lesser likelihood of survival in young SMEs, and 2) profitability in the previous period, age, $R \& D$ expenditure, liquidity, and long-term debt contribute positively to the likelihood survival in old SMEs.

The following Table 5 presents the results of the Chow test of differences between the determinants of survival for young SMEs and old SMEs.

\footnotetext{
${ }^{8}$ In Appendix, Table A1, we present the results relating to the survival analysis of young SMEs and old SMEs, considering the alternative criterion for classifying young and old SMEs previously mentioned in Section 3. Methodology. The results obtained, concerning sign, magnitude and statistical significance of the estimated parameters, are relatively similar to those presented in Table 4, which confirms the robustness of the empirical evidence obtained in this study, regarding specifically the survival analysis carried out.
} 
Table 5. Chow test - differences for determinants of survival - Young SMEs and Old SMEs

\begin{tabular}{cc}
\hline Independent Variables & Dependent Variable: $\operatorname{Pr}\left(\delta_{i, t}=1\right)$ \\
\hline$\left(P F O F_{i, t-1}\right) \alpha_{\text {YOUNG }}-\alpha_{O L D}=0$ & $27.07 * * *$ \\
$F(1.12053)$ & $(0.0000)$ \\
\hline$\left(A G E_{i, t}\right) \tau_{1 Y O U N G}-\tau_{1 O L D}=0$ & $18.91^{* * *}$ \\
$F(1.12053)$ & $(0.0000)$ \\
\hline$\left(R \& D_{i, t}\right) \tau_{2 Y O U N G}-\tau_{2 O L D}=0$ & $32.33^{* * *}$ \\
$F(1.12053)$ & $(0.0000)$ \\
\hline$\left(S I Z E_{i, t}\right) \tau_{3 Y O U N G}-\tau_{3 O L D}=0$ & $21.85^{* * *}$ \\
$F(1.12053)$ & $(0.0000)$ \\
\hline$\left(L I Q_{i, t}\right) \tau_{4 Y O U N G}-\tau_{4 O L D}=0$ & $23.45^{* * *}$ \\
$F(1.12053)$ & $(0.0000)$ \\
\hline$\left(L L E V_{i, t}\right) \tau_{5 Y O U N G}-\tau_{5 O L D}=0$ & $25.06^{* * *}$ \\
$F(1.12053)$ & $(0.0000)$ \\
\hline$\left(E V O L_{i, t}\right) \tau_{6 Y O U N G}-\tau_{6 O L D}=0$ & $24.41^{* * *}$ \\
$F(1.12053)$ & $(0.0000)$ \\
\hline Global Difference & $28.38^{* * *}$ \\
$F(7.12053)$ & $(0.0000)$ \\
\hline
\end{tabular}

Notes: $1 .{ }^{* *}$ statistically significant at $1 \%$ level. 2 . Probabilities in parenthesis

We find that for each of the variables considered as determinants of the survival of young SMEs and old SMEs, we reject the null hypothesis of equality of the estimated parameters regarding the relationships between profitability determinants and probability of survival. The results of the overall Chow test confirm those differences. Therefore, we can conclude that there are statistically significant differences between the survival determinants of young SMEs and old SMEs.

\subsection{Dynamic panel estimators}

The following Table 6 presents the regressions referring to the relationships between determinants and profitability in young SMEs and old SMEs, using the GMM (1991), GMM system (1998) and LSDVC (2005) ${ }^{9}$ estimators.

The results of the Sargan test, regardless of taking young or old SMEs as the subject of analysis, indicate the rejection of the null hypothesis, thus the restrictions arising from the instruments used are valid. Therefore, and in spite of not being able to reject the null hypothesis of second-order autocorrelation, we cannot consider the results obtained with the GMM (1991) estimator valid.

\footnotetext{
${ }^{9}$ In Appendix, Table A2, we present the results referring to the determinants of profitability in young SMEs and old SMEs, taking the alternative criterion for classifying young SMEs and old SMEs presented above in Section 3. Methodology. As for sign, magnitude and statistical significance of the estimated parameters, the results obtained are relatively similar to those presented in Table 6 , which confirms the robustness of the empirical evidence obtained relating to the profitability determinants of young and old SMEs.
} 
Table 6. Determinants of profitability - Young SMEs and Old SMEs

\begin{tabular}{|c|c|c|c|c|c|c|}
\hline \multirow[b]{3}{*}{$\begin{array}{l}\text { Independent } \\
\text { Variables }\end{array}$} & \multicolumn{6}{|c|}{ Dependent Variable: $P F O F_{i, t}$} \\
\hline & \multicolumn{3}{|c|}{ Young SMEs } & \multicolumn{3}{|c|}{ Old SMEs } \\
\hline & $\begin{array}{l}\text { GMM } \\
(1991)\end{array}$ & $\begin{array}{c}\text { GMM } \\
\text { system } \\
(1998)\end{array}$ & $\begin{array}{l}\text { LSDVC } \\
(2005)\end{array}$ & $\begin{array}{l}\text { GMM } \\
(1991)\end{array}$ & $\begin{array}{c}\text { GMM } \\
\text { system } \\
(1998)\end{array}$ & $\begin{array}{l}\text { LSDVC } \\
(2005)\end{array}$ \\
\hline$P F O F_{i, t-1}$ & $\begin{array}{c}0.05647 \\
(0.05097)\end{array}$ & $\begin{array}{c}0.33652 * * * \\
(0.05377)\end{array}$ & $\begin{array}{c}0.32838 * * * \\
(0.05182)\end{array}$ & $\begin{array}{l}0.11928 * * \\
(0.05782)\end{array}$ & $\begin{array}{c}0.55662 * * * \\
(0.06283)\end{array}$ & $\begin{array}{c}0.58929 * * * \\
(0.06721)\end{array}$ \\
\hline$A G E_{i, t}$ & $\begin{array}{c}0.01298 \\
(0.01987)\end{array}$ & $\begin{array}{c}0.05647 * * * \\
(0.01488)\end{array}$ & $\begin{array}{c}0.05093 * * * \\
(0.01238)\end{array}$ & $\begin{array}{c}-0.08732 * * * \\
(0.02189)\end{array}$ & $\begin{array}{c}-0.04087^{* * * *} \\
(0.00956)\end{array}$ & $\begin{array}{c}-0.03723 * * * \\
(0.00834)\end{array}$ \\
\hline$R \& D_{i, t}$ & $\begin{array}{l}-0.00783 \\
(0.05631)\end{array}$ & $\begin{array}{l}-0.02839 \\
(0.06088)\end{array}$ & $\begin{array}{l}-0.04536 \\
(0.07827)\end{array}$ & $\begin{array}{c}0.17362 * * * \\
(0.05076)\end{array}$ & $\begin{array}{c}0.28729 * * * \\
(0.06089)\end{array}$ & $\begin{array}{c}0.24531 * * * \\
(0.05821)\end{array}$ \\
\hline$S I Z E_{i, t}$ & $\begin{array}{c}0.00786 \\
(0.01332)\end{array}$ & $\begin{array}{c}0.05529 * * * \\
(0.01245)\end{array}$ & $\begin{array}{c}0.04973 * * * \\
(0.00901)\end{array}$ & $\begin{array}{c}-0.02738^{*} \\
(0.01407)\end{array}$ & $\begin{array}{c}0.01943^{* *} \\
(0.0091)\end{array}$ & $\begin{array}{c}0.02223 * * * \\
(0.00665)\end{array}$ \\
\hline$L I Q_{i, t}$ & $\begin{array}{c}0.11889 * * * \\
(0.03006)\end{array}$ & $\begin{array}{c}0.07998^{* * * *} \\
(0.02366)\end{array}$ & $\begin{array}{c}0.07453 * * * \\
(0.02112)\end{array}$ & $\begin{array}{l}-0.00984 \\
(0.03118)\end{array}$ & $\begin{array}{c}0.01342 \\
(0.03749)\end{array}$ & $\begin{array}{c}0.00982 \\
(0.03440)\end{array}$ \\
\hline$L L E V_{i, t}$ & $\begin{array}{c}0.02832 \\
(0.03098)\end{array}$ & $\begin{array}{c}0.07983 * * * \\
(0.01665)\end{array}$ & $\begin{array}{c}0.08631 * * * \\
(0.01774)\end{array}$ & $\begin{array}{l}-0.00654 \\
(0.01449)\end{array}$ & $\begin{array}{c}0.00768 \\
(0.02009)\end{array}$ & $\begin{array}{l}-0.01778 \\
(0.02344)\end{array}$ \\
\hline$E V O L_{i, t}$ & $\begin{array}{c}-0.01678^{*} \\
(0.00903)\end{array}$ & $\begin{array}{c}-0.02117 * * * \\
(0.00568)\end{array}$ & $\begin{array}{c}-0.01672 * * \\
(0.00789)\end{array}$ & $\begin{array}{c}0.02298 \\
(0.04415)\end{array}$ & $\begin{array}{c}0.01982 \\
(0.03844)\end{array}$ & $\begin{array}{c}0.00783 \\
(0.03223)\end{array}$ \\
\hline$\lambda_{i, t}$ & $\begin{array}{c}-0.10983 * * * \\
(0.02738)\end{array}$ & $\begin{array}{c}-0.12837 * * * \\
(0.02879)\end{array}$ & $\begin{array}{c}-0.16374 * * * \\
(0.03098)\end{array}$ & $\begin{array}{c}-0.14783 * * * \\
(0.02873)\end{array}$ & $\begin{array}{c}-0.13047^{* * * *} \\
(0.02534)\end{array}$ & $\begin{array}{c}-0.17005^{* * *} \\
(0.03228)\end{array}$ \\
\hline CONS & $\begin{array}{c}0.01234 \\
(0.03829)\end{array}$ & $\begin{array}{c}0.02346 \\
(0.04092)\end{array}$ & & $\begin{array}{l}0.02839 * * \\
(0.01367)\end{array}$ & $\begin{array}{l}0.02773 * \\
(0.01409)\end{array}$ & \\
\hline Wald & $169.43^{* * *}$ & & & $156.04 * * *$ & & \\
\hline $\mathrm{F}$ & & $97.04 * * *$ & & & $81.12 * * *$ & \\
\hline Sargan & $41.02 * * *$ & & & $38.49 * * *$ & & \\
\hline Hansen & & 135.10 & & & 126.61 & \\
\hline $\mathrm{m}_{1}$ & $-6.04 * * *$ & $-6.35 * * *$ & & $-5.32 * * *$ & $-5.11 * * *$ & \\
\hline $\mathrm{m}_{2}$ & -0.37 & -0.25 & & -0.32 & -0.48 & \\
\hline Firms & 459 & 459 & 459 & 1188 & 1188 & 1188 \\
\hline Observations & 2064 & 2523 & 2523 & 5940 & 7128 & 7128 \\
\hline
\end{tabular}

Notes: Robust Standard Deviations in parenthesis. 2. ***statistically significant at $1 \%$ level; **statistically significant at $5 \%$ level; and *statistically significant at $10 \%$ level. 3. Estimations include sector dummy variables, but estimated parameters are not presented in the tables. 4. Estimates include annual dummy variables, but estimated parameters are not presented in the tables

Whether taking young or old SMEs as the subject of analysis, the results of the Hansen test indicate that we cannot reject the null hypothesis of validity of the restrictions, as a consequence of the instruments used. What is more, whether taking young or old SMEs as the subject of analysis, the results of the second-order autocorrelation tests indicate that we cannot reject the null hypothesis of absence of second-order autocorrelation. Based on the results of the Hansen, and second-order autocorrelation tests, we can conclude that the results obtained with the GMM system (1998) estimator are robust. 
The results obtained with the LSDVC (2005) estimator corroborate, in general, those obtained with the GMM system (1998), regarding the sign, magnitude and statistically significance of the estimated parameters.

Based on the various results obtained, we will consider the empirical evidence from using the GMM system (1998) and LSDVC (2005) estimators as our reference for interpreting the results.

Regarding the relationships between determinants and profitability in young SMEs, we can conclude that: 1) profitability in the previous period, age, size, liquidity and longterm debt positively influence profitability, while risk negatively influences profitability.

For old SMEs, we can conclude that: 1) profitability in the previous period, R\&D expenditure, and size influence positively profitability, while age influences negatively profitability.

Regarding the relationship between the inverse Mill's ratio and profitability, we identify negative and statistically significant relationships, regardless of taking young SMEs or old SMEs as the subject of analysis. This empirical evidence obtained allows us to conclude that using the inverse Mill's ratio seems to be effective in solving the problem of possible result bias as a consequence of the matter of survival. Indeed, not considering the inverse Mill's ratio in the regressions would lead to overvaluation of the estimated parameters.

The following Table 7 presents the results of the Chow test of differences in the estimated parameters measuring the relationships between determinants and profitability in young and old SMEs.

Table 7. Chow test - determinants of profitability - Young SMEs and Old SMEs

\begin{tabular}{ccc}
\hline Independent Variables & \multicolumn{2}{c}{ Dependent Variable: $P F O F_{i, t}$} \\
\hline$\left(P F O F_{i, t-1}\right) \delta_{\text {YOUNG }}-\delta_{\text {OLD }}=0$ & GMM system $(1998)$ & LSDVC $(2005)$ \\
$F(1.9651)$ & $22.78^{* * *}$ & $24.55^{* * *}$ \\
$\left(A G E_{i, t}\right) \beta_{1 \text { YOUNG }}-\beta_{1 O L D}=0$ & $30.98^{* * *}$ & $(0.0000)$ \\
$F(1.9651)$ & $(0.0000)$ & $28.98^{* * *}$ \\
$\left(R \& D_{i, t}\right) \beta_{2 Y O U N G}-\beta_{2 O L D}=0$ & $32.67^{* * *}$ & $(0.0000)$ \\
$F(1.9651)$ & $(0.0000)$ & $30.77^{* * *}$ \\
\hline$\left(S I Z E_{i, t}\right) \beta_{3 Y O U N G}-\beta_{3 O L D}=0$ & $14.89^{* * *}$ & $(0.0000)$ \\
$F(1.9651)$ & $(0.0000)$ & $11.43^{* * *}$ \\
\hline$\left(L I Q_{i, t}\right) \beta_{4 Y O U N G}-\beta_{4 O L D}=0$ & $24.54^{* * *}$ & $(0.0000)$ \\
$F(1.9651)$ & $(0.0000)$ & $23.12^{* * *}$ \\
\hline$\left(L L E V_{i, t}\right) \beta_{5 Y O U N G}-\beta_{5 O L D}=0$ & $25.99^{* * *}$ & $(0.0000)$ \\
$F(1.9651)$ & $(0.0000)$ & $27.53^{* * *}$ \\
\hline$\left(E V O L_{i, t}\right) \beta_{6 Y O U N G}-\beta_{6 O L D}=0$ & $18.58^{* * *}$ & $(0.0000)$ \\
$F(1.9651)$ & $(0.0000)$ & $15.67^{* * *}$ \\
\hline Global Difference & $30.53^{* * *}$ & $(0.0000)$ \\
$F(7.9651)$ & $(0.0000)$ & $31.04 * * *$ \\
\hline
\end{tabular}

Notes: $1 .{ }^{* * *}$ significant at $1 \%$ level; 2 . Probabilities in parenthesis 
Whether using the GMM system (1998) estimator or the LSDVC (2005) estimator, we reject the null hypothesis of equality of estimated parameters for the relationships between the determinants considered and profitability in young and old SMEs. The results show that there are differences between young SMEs and old SMEs for the relationships between determinants and profitability.

\section{Discussion of the results}

There is a positive relationship between age and profitability in young SMEs, the relationship being negative in the case of old SMEs. Therefore, age has greater relative importance for increased profitability in young SMEs than for increased profitability in old SMEs, and so we can accept the previously formulated hypothesis H1.

The arguments of Jovanovic (1982) are not totally corroborated by the empirical evidence obtained in this study. In fact, greater SME age only implies increased profitability for young SMEs, but this is not verified by SMEs in more advanced stages of their life-cycle. Indeed, when SMEs are young, the relative marginal importance of age for increased profitability is relevant.

The fact that young SMEs are more proactive and more careful in choosing their investments (Lumpkin 1998; Shane, Venkataraman 2000) may contribute to the empirical evidence obtained in this study. The need to survive, and consequently the need to be more proactive and more selective with investments, together with the marginal effect of one more year of acquired experience, in the first years of the life-cycle, may be decisive for age contributing positively to increased profitability in young SMEs, which does not occur in the case of old SMEs.

The empirical evidence indicates that $\mathrm{R} \& \mathrm{D}$ expenditure is more important for increased profitability in old SMEs than in young SMEs. Indeed, we find a statistically insignificant relationship between $R \& D$ expenditure and profitability in young SMEs, whereas the relationship between $\mathrm{R} \& \mathrm{D}$ expenditure and profitability in old SMEs is positive and statistically significant. This being so, we can accept the previously formulated hypothesis $\mathrm{H} 2$.

The forecast benefits regarding the impact of $\mathrm{R} \& \mathrm{D}$ expenditure on SME profitability: 1) greater organizational flexibility, and consequently greater efficiency in taking advantage of good growth opportunities (Rogers 2004); 2) greater diversification of activities, and consequently greater export capacity (Beise-Zee, Rammer 2006); and 3 ) greater ability to establish cooperation networks, and consequently greater possibility to diversify activities (Rickne 2006); only seem to be relevant in the case of old SMEs.

The principal goal of young SMEs to reach the minimum scale of efficiency that allows survival (Jovanovic 1982) may contribute to less efficient use of R \& D investment, corroborating the arguments of Müller and Zimmermann (2009), regarding the need of the learning effect for SMEs to become efficient in managing R\&D expenditure. Indeed, the empirical evidence obtained indicates that the learning effect may be important for R \& D expenditure to imply increased profitability. In addition, we find that old SMEs have greater average liquidity than young SMEs. The greater flexibility in managing 
financial resources may contribute to old SMEs being more efficient in managing R \& D expenditure than young SMEs, since the young firms face greater stress in managing their resources as a consequence of possible lower liquidity (Tanabe, Watanabe 2005; Gomez, Vargas 2009; Müller, Zimmermann 2009).

For young and old SMEs, there is a positive and statistically significant relationship between size and profitability. However, the positive impact of size on profitability is greater for young SMEs than for old ones, which is corroborated by the result of the Chow test. Based on the empirical evidence obtained, we can conclude that size takes on greater relative importance for increased profitability in young SMEs than for increased profitability in old SMEs, and so we can accept the previously formulated hypothesis $\mathrm{H} 3$.

The benefits of greater size for profitability forecasted by various authors (Winter 1994; Hardwick 1997; Wyn 1998; Gschwandtner 2005): 1) greater capacity to take advantage of economies of scale; 2) greater capacity to diversify activities and products; and 3) greater ability to implement strategies seeking to raise barriers to the entry of potential competitors, seem to be more important for increased profitability in young SMEs than for increased profitability in old SMEs.

The positive impact of size in profitability is greater for young SMEs than do for old SMEs, which may be related to a greater proximity to the minimum size of efficiency that allows young SMEs to survive in their operating markets. Greater size of young SMEs, and the consequent approach to the minimum size of efficiency that allows survival, may contribute to young SMEs being able to manage their resources more efficiently. Therefore, size is a greater importance for increased profitability in young SMEs.

As would be expected, given that in most cases SME ownership and management is concentrated in the same individuals, regardless of taking young or old SMEs as the subject of analysis, greater size does not imply diminished profitability. Therefore, the reasoning of Pi and Timme (1993) and Goddard et al. (2005) regarding that greater size may contribute to managers to invest in projects that harm profitability does not appear to be relevant in SMEs.

We find that the relationship between liquidity and profitability is positive and statistically significant for young SMEs, but it is not statistically significant in the case of old SMEs. Therefore, we can conclude that liquidity has greater relative importance for increased profitability in young SMEs than in old SMEs, and so we can accept the previously formulated hypothesis $\mathrm{H} 4$.

The fact that greater liquidity contributes to SMEs being able to manage their financial resources with less stress, allowing them to deal successfully with possible changes in their operating markets (Goddard et al. 2005), seems to have greater importance for higher levels of profitability in young SMEs, compared to what occurs in old SMEs.

The conclusions by Honjo and Harada (2006) seem to be particularly relevant in the context of young SMEs. Indeed, less stress in managing financial resources may be fundamental in the first years of the life-cycle of SMEs, so that these firms can implement their investment opportunities, which contributes to increased levels of profitability. 
The impossibility to accomplish the short-term commitments, and the consequent stress in managing financial resources can be particularly important for SMEs in the first years of their life-cycle. Therefore, greater liquidity may be particularly important for reducing the impossibility of young SMEs to accomplish their short-term commitments, leading to less stress in managing their financial resources, which can be decisive for young SMEs to improve their levels of profitability. However, young SMEs face more problems of liquidity due to less reputation (Diamond 1989), and a greater probability of bankruptcy (Müller, Zimmermann 2009), which contributes for creditors make it difficult for young SMEs to obtain debt (Serrasqueiro, Maçãs Nunes 2010), compared to old SMEs.

It should also be noted that, whether taking young or old SMEs as the subject of analysis, greater liquidity does not imply lower levels of profitability. According to Ang (1991) that situation occurs, because for the majority of SMEs, ownership and management are in the same hands, so the agency problems between owners and managers being minimal. However, our results do not corroborate the arguments of Fama and Jensen (1983) and Myers and Rajan (1995) that greater liquidity can contribute to managers to invest in projects that do not contribute to increased profitability, but rather to increasing their personal benefits.

We find a positive and statistically significant relationship between long-term debt and profitability in young SMEs, but that relationship being statistically insignificant when our subject of analysis is old SMEs. Based on this empirical evidence, we may conclude that long-term debt is of greater relative importance for increased profitability in young SMEs than for increased profitability in old SMEs, and so we can accept the previously formulated hypothesis $\mathrm{H} 5$.

When internal financing is insufficient, access to long-term debt seems to be fundamental for increased profitability in young SMEs. The considerable risk associated with the activities of young SMEs may imply particularly restrictive terms of credit imposed by creditors (Myers 1977). Consequently, young SMEs may become excessively dependent on short-term debt, when internal funding is insufficient. Given the high dependence on short-term debt, when internal financing is insufficient, the marginal effect of long-term debt on the profitability can be particularly relevant in young SMEs

The empirical evidence obtained in the context of young SMEs seems corroborate the arguments of Fagiolo and Luzzi (2006), given that use of long-term debt can be fundamental for those firms being able to reduce possible excessive stress in managing their financial resources, as a consequence of the need to pay off short-term debts over a short and constant period. Indeed, as Serrasqueiro and Maçãs Nunes (2010) conclude, when internal financing is insufficient, young SMEs are particularly dependent on short-term debt. Young SMEs with less reputation and a greater possibility of bankruptcy may face more obstacles in obtaining long-term debt.

Given the high dependency of young SMEs on short-term debt, when internal financing is insufficient, then the marginal effect of long-term debt on young SME profitability can be particularly relevant. That effect may diminish as SMEs progress in the stages of 
their life-cycle, given the greater possibility of accessing long-term debt, as suggested by the results of the descriptive statistics presented previously.

The relationship between risk and profitability is negative and statistically significant for young SMEs, but it not statistically significant for old SMEs. On the basis of these results, we can accept the previously formulated hypothesis H6.

Creditors can make it difficult for SMEs with high levels of risk to obtain debt (Pettit, Singer 1985). Restrictive credit terms for SMEs can be particularly severe, considering that, asides from the SME greater possibility of bankruptcy, they may change their asset composition, contributing considerably to greater risk meaning diminished profitability in young SMEs. In addition, high risk combined with a high possibility of bankruptcy in young SMEs may contribute to their owners/managers to implement investment projects that maximize their immediate benefits, but they do not mean increased profitability.

A great number of young SMEs have not yet reached the minimum scale of efficiency that allows them to survive (Jovanovic 1982), which may contribute to high-risk situations that do not allow them to take advantage of good investment opportunities. This may occurs in the first years of young SME life-cycle, contributing to reduced levels of profitability.

Finally, whether taking young SMEs or old SMEs as the subject of analysis, the empirical evidence indicates that the relationship between profitability in the previous and present periods is statistically significant. However, for young SMEs the estimated parameter is 0,33652 , when using the GMM system (1998) estimator, and 0.32838 with use of the LSDVC (2005) estimator. For old SMEs, the estimated parameter is 0.55662 , using the GMM system (1998) estimator, and 0.58929, using the LSDVC (2005) estimator. The results of the Chow test show that the estimated parameters are of a different magnitude. Therefore, we find that persistence of profitability is greater in old SMEs than in young SMEs, and so we can accept the previously formulated hypothesis $\mathrm{H} 7$.

The empirical evidence obtained in this study corroborates the conclusions of Mueller (1986), since profitability is persistent in the case of young and old SMEs. This may be due to the dynamic profile of the existing markets, thereby small divergences occurring at certain times can be solved by firms entering and leaving the markets.

In addition, the empirical evidence appears to corroborate the conclusions of Gschwandtner (2005), since greater risk, and consequently greater likelihood of bankruptcy in young SMEs, may contribute to less persistence of profitability.

\section{Conclusion and implications}

Considering two sub-samples of SMEs: 1) 495 young SMEs; and 2) 1350 old SMEs, using the two-step estimation method in order to address possible data bias, arising from the matter of survival, this study investigates whether the determinants of profitability in young SMEs are different from those in old SMEs.

The empirical evidence obtained indicates that age is a determinant factor in the relationships between determinants and profitability in SMEs. 
Firstly, age and size are of greater relative importance for increased profitability in young SMEs than for increased profitability in old SMEs. Moreover, age and size are also found to be relevant for increased probability of survival in young SMEs. Greater age and size can also be particularly relevant for SMEs being able to efficiently diversify activities and products, attaining more quickly the minimum scale of efficiency, thereby contributing to increased profitability in young SMEs.

Secondly, liquidity and long-term debt are of greater relative importance for increased profitability in young SMEs than for increased profitability in old SMEs. Liquidity and long-term debt are also found to be particularly important for increased probability of survival in young SMEs. When internal finance is insufficient, less financial stress in managing financial resources, as a consequence of greater liquidity and access to longterm debt, is particularly important for young SMEs to take advantage of good investment opportunities, arising in the start of their life-cycle, which can imply increased profitability.

Thirdly, R\&D expenditure is more important for increased profitability in old SMEs than in young SMEs. In addition, R\&D expenditure is relevant for increased likelihood of survival in old SMEs. On the one hand, R\&D expenditure can be particularly relevant for SMEs being able to diversify their activities, in advanced stages of their life-cycle. Diversification can imply increased profitability; on the other hand, young SMEs may not make very efficient use of $\mathrm{R} \& \mathrm{D}$ expenditure, due to adverse financial restrictions that SMEs face in the first years of activity, as well as little experience in managing R\&D projects.

Fourthly, risk is of greater relative importance for diminished profitability in young SMEs than for diminished profitability in old SMEs. We also find that risk contributes to less survival in young SMEs. The difficulties to obtain debt faced by young SMEs, the possibility of owners/managers investing in projects that do not maximize profitability, and the possibility of high risk situations implying the rejection of good investment opportunities, are all factors that impose higher levels of risk, which may imply reduced profitability in young SMEs.

Fifthly, persistence of profitability is greater in old SMEs than in young SMEs. Additionally, profitability in the previous period is of greater relative importance for increased probability of survival in young SMEs than for increased probability of survival in old SMEs. The particular difficulties that young SMEs may face in the start of their life-cycle, namely the possible changes of the market conditions, and difficulties in managing financial resources, can contribute to less persistence of profitability in this type of SME, compared to the case of old SMEs.

The empirical evidence obtained in this study allows us to make the following suggestions for economic policy in general and industrial policy in particular.

It is suggested that the Portuguese government should promote useful support to young SMEs, through the creation of special long-term lines of credit, which would mean less stress in managing financial resources, allowing young SMEs to take advantage of good investment opportunities, arising in the start of their life-cycle, contributing to increased 
profitability. For old SMEs, given the importance of R\&D expenditure for increased profitability and the probability of survival, we suggest measures that contemplate financial support for investment in R \& D, so that this type of SME can diversify their activities and products, thereby stimulating their levels of profitability.

\section{Acknowledgements}

The authors thank the three anonymous referees for their comments. Paulo Maçãs Nunes and Zélia Serrasqueiro also gratefully acknowledge partial financial support from FCT, program POCTI. Ana Viveiros also gratefully acknowledge financial support from BPI (Banco Português de Investimento).

\section{References}

Adams, M.; Buckle, M. 2003. The determinants of corporate financial performance in the Bermuda insurance market, Applied Financial Economics 13: 133-143.

http://dx.doi.org/10.1080/09603100210105030

Amato, L.; Amato, C. 2004. Firm size, strategic advantage, and profit rates in US retailing, Journal of Retailing and Consumer Services 11: 181-193.

http://dx.doi.org/10.1016/S0969-6989(03)00036-5

Andries, P.; Debackere, K. 2007. Adaptation and performance in new businesses: understanding the moderating effects of independence and industry, Small Business Economics 9: 81-99. http://dx.doi.org/10.1007/s11187-005-5640-2

Ang, J. 1991. Small business uniqueness and the theory of financial management, The Journal of Small Business Finance 1: 1-13.

Arellano, M.; Bond, S. 1991. Some tests of specification for panel data: Monte Carlo evidence and an application to employment equations, Review of Economic Studies 58: 277-297.

http://dx.doi.org/10.2307/2297968

Bain, J. 1956. Barriers to New Competition. Harvard University Press, Cambridge, MA.

Barney, J. 2001. Resource-based theories of competitive advantage: a ten year retrospective on the resource based view, Journal of Management 27: 643-650.

http://dx.doi.org/10.1177/014920630102700602

Beise-Zee, R.; Rammer, C. 2006. Local user-producer interaction in innovation and export performance of firms, Small Business Economics 27: 207-222.

http://dx.doi.org/10.1007/s11187-006-0013-z

Blundell, M.; Bond, S. 1998. Initial conditions and moment restrictions in dynamic panel data models, Journal of Econometrics 87: 115-143. http://dx.doi.org/10.1016/S0304-4076(98)00009-8

Bruno, G. 2005. Approximating the bias of LSDV estimator for dynamic unbalanced panel data models, Economic Letters 87: 361-366. http://dx.doi.org/10.1016/j.econlet.2005.01.005

Callen, J.; Cheung, C.; Kwan, C.; Yip, B. 1993. An empirical investigation of the random character of annual earnings, Journal of Accounting, Auditing and Finance 8: 151-162.

Chan, L.; Karceski, J.; Lakonishok, J. 2003. The level and persistence of growth rates, The Journal of Finance 58: 643-684. http://dx.doi.org/10.1111/1540-6261.00540

Deloof, M. 2003. Does working capital management affect profitability of Belgian firms, Journal of Business Finance and Accounting 30: 573-588. http://dx.doi.org/10.1111/1468-5957.00008

Diamond, D. 1989. Reputation acquisition in debt markets, Journal of Political Economy 97: 828-862. http://dx.doi.org/10.1086/261630

Fagiolo, G.; Luzzi, A. 2006. Do liquidity constrains matter in explaining firm size and growth? Some evidence from the Italian manufacturing industry, Industrial and Corporate Change 15: 1-39. http://dx.doi.org/10.1093/icc/dtj001 
Fama, E.; Jensen, M. 1983. Agency problems and residual claims, Journal of Law and Economics 26: 327-349. http://dx.doi.org/10.1086/467038

Ferrando, A.; Köhler-Ulbrich, P.; Pál, R. 2007. Is the growth of euro area small and medium-sized enterprises constrained by financing barriers?, in Conference Proceedings of Financial Management Association. Barcelona, Spain.

Galbreath, J.; Galvin, P. 2008. Firms factors, industry structure and performance variation: new empirical evidence to a classic debate, Journal of Business Research 61: 109-117.

http://dx.doi.org/10.1016/j.jbusres.2007.06.009

Goddard, J.; Tavakoli, M.; Wilson, J. 2005. Determinants of profitability in European manufacturing and services: evidence from a dynamic panel data, Applied Financial Economics 15: 1269-1282. http://dx.doi.org/10.1080/09603100500387139

Gomez, J.; Vargas, P. 2009. The effect of financial constraints, absorptive capacity and complementarities on the adoption of multiple process technologies, Research Policy 38: 106-119.

http://dx.doi.org/10.1016/j.respol.2008.10.013

Gschwandtner, A. 2005. Profit persistence in the 'very' long run: evidence from survivors and exiters, Applied Economics 37: 793-806.

http://dx.doi.org/10.1080/0003684042000337406

Hardwick, P. 1997. Measuring cost inefficiency in the UK life insurance industry, Applied Financial Economics 7: 37-44. http://dx.doi.org/10.1080/096031097333835

Heckman, J. 1979. Sample selection bias as a specification error, Econometrica 47: 153-161. http://dx.doi.org/10.2307/1912352

Honjo, Y.; Harada, N. 2006. SME policy, financial structure and firm growth: evidence from Japan, Small Business Economics 27: 289-300. http://dx.doi.org/10.1007/s11187-005-6703-0

Hyytinen, A.; Pajarinen, M. 2004. Is the cost of debt capital higher for younger firms? The research institute of the finnish economy, Discussion Paper N$^{\circ} .946$.

IAPMEI. 2008. Sobre as PMEs em Portugal. Instituto de Apoio à Pequena e Média Empresa: Lisboa.

Jensen, M.; Meckling, W. 1976. Theory of the firm: managerial behaviour, agency costs and ownership structure, Journal of Financial Economics 3: 306-360.

http://dx.doi.org/10.1016/0304-405X(76)90026-X

Jovanovic, B. 1982. Selection and evolution of industry, Econometrica 50: 649-670.

http://dx.doi.org/10.2307/1912606

La Rocca, M.; La Rocca, T.; Cariola, A. 2009. Capital structure decisions during a firm's life cycle, Small Business Economics (first forthcoming): 1-24.

Lamm-Tennant, J.; Starks, L. 1993. Stock versus mutual ownership structures: the risk implications, Journal of Business 66: 29-46. http://dx.doi.org/10.1086/296592

Levinthal, D. 1995. Strategic management and the exploration of diversity, in Montgomery, C. A. (Ed.). Resource-Based and Evolutionary Theories of the Firm. Kluwer, Norwell, MA.

http://dx.doi.org/10.1007/978-1-4615-2201-0_2

Lotti, F.; Santarelli, E.; Vivarelli, M. 2009. Defending Gibrat's law as a long - run regularity, Small Business Economics 32: 31-44. http://dx.doi.org/10.1007/s11187-007-9071-0

Lumpkin, G. 1998. Do New Entrants Have an Entrepreneurial Orientation? Paper Presented at the 1998 Academy of Management Meeting. San Diego, CA.

Lumpkin, G.; Dess, G. 1996. Clarifying the entrepreneurial orientation construct and linking it to performance, Academy of Management Review 21: 135-172.

Maçãs Nunes, P.; Serrasqueiro, Z.; Leitão, J. 2010. Are there non linear relationship between the profitability of Portuguese services SMEs and its specific determinants?, The Services Industries Journal 30: 1313-1341. http://dx.doi.org/10.1080/02642060802398853 
Maçãs Nunes, P.; Serrasqueiro, Z.; Sequeira, T. 2009. Profitability in Portuguese service firms: a panel data approach, The Services Industries Journal 29: 693-707.

http://dx.doi.org/10.1080/02642060902720188

Moreno, J.; Castillo, L.; Masere, E. 2010. Firm size and entrepreneurial characteristics: evidence from the SME sector in Argentina, Journal of Business Economics and Management 11: 259-282. http://dx.doi.org/10.3846/jbem.2010.13

Moreno, J.; Castillo, L. 2011. Corporate growth, age and ownership structure: empirical evidence in Spanish firms, Journal of Business Economics and Management 12: 164-196.

http://dx.doi.org/10.3846/16111699.2011.555449

Mueller, D. 1986. Profits in the Long- Run. Cambridge University Press, Cambridge.

Müller, E.; Zimmermann, V. 2009. The importance of equity finance for R\&D activity, Small Business Economics 33: 303-318. http://dx.doi.org/10.1017/CBO9780511664731

Myers, S. 1977. Determinants of corporate borrowing, Journal of Financial Economics 5: 147-175.

Myers, S.; Rajan, R. 1995. Liquidity and the rise of financial intermediation, in Proceedings, Federal Reserve Bank of Chicago (issue May), 427-446.

http://dx.doi.org/10.1016/0304-405X(77)90015-0

Oliveira, B.; Fortunato, A. 2006. Firm growth and liquidity constraints: a dynamic analysis, Small Business Economics 27: 139-156. http://dx.doi.org/10.1007/s11187-006-0006-y

Peteraf, M. 1993. The cornerstoners of competitive advantage: a resource based view, Strategic Management Journal 14: 179-191. http://dx.doi.org/10.1002/smj.4250140303

Pettit, R.; Singer, R. 1985. Small business finance: a research agenda, Financial Management 14: 47-60. http://dx.doi.org/10.2307/3665059

Pi, L.; Timme, S. 1993. Corporate control and bank efficiency, Journal of Banking and Finance 17: 515-530. http://dx.doi.org/10.1016/0378-4266(93)90050-N

Porter, M. 1980. Competitive Strategy: Techniques for Analysing Industries and Competitors. New York: The Free Press.

Rickne, A. 2006. Connectivity and performance of science-based firms, Small Business Economics 26: 393-407. http://dx.doi.org/10.1007/s11187-005-4848-5

Robb, A.; Robinson, D. 2009. The capital structure decisions of new firms, Working Paper.

Rogers, M. 2004. Networks, firm size and innovation, Small Business Economics 22: 141-153. http://dx.doi.org/10.1023/B:SBEJ.0000014451.99047.69

Serrasqueiro, Z.; Maçãs Nunes, P. 2010. Is age a determinant of financing decisions of SMEs? Empirical evidence using panel data models, Entrepreneurship Theory and Practice (forthcoming). http://dx.doi.org/10.1007/s11187-007-9092-8

Serrasqueiro, Z.; Maçãs Nunes, P. 2008. Performance and size: empirical evidence from Portuguese SMEs, Small Business Economics 31: 195-217.

Shane, S.; Venkataraman, S. 2000. The promise of entrepreneurship as a field of research, Academy of Management Review 25: 217-226.

Slater, S.; Olsen, E. 2002. A fresh look at industry and market analysis, Business Horizons (sp suppl.): 15-22.

Steffens, P.; Davidsson, P.; Fitzsimmons, J. 2009. Performance configurations over time: implications for growth-and profit, oriented strategies, Entrepreneurship Theory and Practice 33: 125-148. http://dx.doi.org/10.1111/j.1540-6520.2008.00283.x

Stulz, R. 1990. Managerial discretion and optimal financing policies, Journal of Financial Economics 26: 3-27. http://dx.doi.org/10.1016/0304-405X(90)90011-N

Tanabe, K.; Watanabe, C. 2005. Sources of small and medium firms excellent business performance in a service oriented economy, Journal of Services Research 5: 5-20. 
Teece, D. 1981. Internal organization and economic performance: an empirical analysis of the profitability of principal firms, Journal of Industrial Economics 30: 173-199.

http://dx.doi.org/10.2307/2098201

Titman, S.; Wessels, R. 1988. The determinants of capital structure choice, Journal of Finance 43: 1-19. http://dx.doi.org/10.2307/2328319

Travkina, I.; Tvaronaviciene, M. 2011. Export competitiveness and domestic productivity facets: case of Lithuania, Journal of Business Economics and Management 12: 49-68.

http://dx.doi.org/10.3846/16111699.2011.555360

Winter, R. 1994. The dynamics of competitive insurance markets, Journal of Financial Intermediation 3: 379-415. http://dx.doi.org/10.1006/jfin.1994.1011

Wyn, J. 1998. The fourth wave, Best's Review 99: 53-57.

Yasuda, T. 2005. Firm growth, size, age and behaviour in Japanese manufacturing, Small Business Economics 24: 1-15. http://dx.doi.org/10.1007/s11187-005-7568-y

\section{APPENDIX}

\section{Alternative criterion for selecting SMEs based on age}

Table A1. Analysis of survival - Young SMEs and Old SMEs - alternative criterion for selecting SMEs based on age

\begin{tabular}{ccc}
\hline & Dependent Variable: $\operatorname{Pr}\left(\delta_{i, t}=1\right)$ & \\
\hline Independent Variables & Young SMEs & Old SMEs \\
\hline$P F O F_{i, t-1}$ & $0.58748^{* * *}$ & $0.16445^{* * *}$ \\
& $(0.06758)$ & $(0.04336)$ \\
\hline$A G E_{i, t}$ & $0.11334^{* * *}$ & $0.05112^{* * *}$ \\
& $(0.03456)$ & $(0.01503)$ \\
\hline$R \& D_{i, t}$ & 0.05998 & $0.35009^{* * *}$ \\
& $(0.11546)$ & $(0.11637)$ \\
\hline$S I Z E_{i, t}$ & $0.16112^{* * *}$ & 0.01114 \\
& $(0.03453)$ & $(0.02874)$ \\
\hline$L I Q_{i, t}$ & $0.21123^{* * *}$ & $0.08544^{* *}$ \\
& $(0.06473)$ & $(0.04221)$ \\
\hline$L L E V_{i, t}$ & $0.26758^{* * *}$ & $0.10394 *$ \\
& $(0.06758)$ & $(0.05303)$ \\
\hline$E V O L_{i, t}$ & $-0.04993 * * *$ & -0.00194 \\
& $(0.01687)$ & $(0.01599)$ \\
\hline Pseudo $R^{2}$ & 0.4545 & 0.38394 \\
\hline Firms & 236 & 1609 \\
\hline Observations & 1228 & 10543 \\
\hline Robust Stan & &
\end{tabular}

Notes: 1. Robust Standard Deviations in parenthesis. $2 .{ }^{* * *}$ statistically significant at $1 \%$ level; $* *$ statistically significant at 5\% level; and *statistically significant at $10 \%$ level. 3. Estimations include sector dummy variables, but estimated parameters are not presented in the tables. 4. Estimates include annual dummy variables, but estimated parameters are not presented in the tables 
Table A2. Determinants of profitability - Young SMEs and Old SMEs - alternative criterion for selecting SMEs based on age

\begin{tabular}{|c|c|c|c|c|c|c|}
\hline \multirow[b]{3}{*}{$\begin{array}{l}\text { Independent } \\
\text { Variables }\end{array}$} & \multicolumn{6}{|c|}{ Dependent Variable: $P F O F_{i, t}$} \\
\hline & \multicolumn{3}{|c|}{ Young SMEs } & \multicolumn{3}{|c|}{ Old SMEs } \\
\hline & $\begin{array}{l}\text { GMM } \\
(1991)\end{array}$ & $\begin{array}{c}\text { GMM } \\
\text { system } \\
(1998)\end{array}$ & $\begin{array}{l}\text { LSDVC } \\
(2005)\end{array}$ & $\begin{array}{l}\text { GMM } \\
(1991)\end{array}$ & $\begin{array}{c}\text { GMM } \\
\text { system } \\
(1998)\end{array}$ & $\begin{array}{c}\text { LSDVC } \\
(2005)\end{array}$ \\
\hline$P F O F_{i, t-1}$ & $\begin{array}{c}0.02839 \\
(0.04758)\end{array}$ & $\begin{array}{c}0.28939 * * * \\
(0.04556)\end{array}$ & $\begin{array}{c}0.29094 * * * \\
(0.04778)\end{array}$ & $\begin{array}{c}0.14656^{* * *} \\
(0.04656)\end{array}$ & $\begin{array}{c}0.52888^{* * * *} \\
(0.05436)\end{array}$ & $\begin{array}{c}0.55463 * * * \\
(0.05553)\end{array}$ \\
\hline$A G E_{i, t}$ & $\begin{array}{c}0.02009 \\
(0.02455)\end{array}$ & $\begin{array}{c}0.07384 * * * \\
(0.015647)\end{array}$ & $\begin{array}{c}0.06112 * * * \\
(0.01454)\end{array}$ & $\begin{array}{c}-0.06473 * * * \\
(0.01441)\end{array}$ & $\begin{array}{c}-0.03529 * * * \\
(0.00837)\end{array}$ & $\begin{array}{c}-0.03223 * * * \\
(0.00777)\end{array}$ \\
\hline$R \& D_{i, t}$ & $\begin{array}{l}-0.00453 \\
(0.05226)\end{array}$ & $\begin{array}{l}-0.01546 \\
(0.05778)\end{array}$ & $\begin{array}{l}-0.04098 \\
(0.07512)\end{array}$ & $\begin{array}{c}0.19283 * * * \\
(0.05779)\end{array}$ & $\begin{array}{c}0.26375^{* * * *} \\
(0.05646)\end{array}$ & $\begin{array}{c}0.22231 * * * \\
(0.05449)\end{array}$ \\
\hline$S I Z E_{i, t}$ & $\begin{array}{c}0.02343 * * \\
(0.01133)\end{array}$ & $\begin{array}{c}0.06654 * * * \\
(0.01477)\end{array}$ & $\begin{array}{c}0.06556 * * * \\
(0.001123)\end{array}$ & $\begin{array}{l}-0.02009 \\
(0.02736)\end{array}$ & $\begin{array}{l}0.01134^{*} \\
(0.05882)\end{array}$ & $\begin{array}{c}0.02637 * * * \\
(0.005444)\end{array}$ \\
\hline$L I Q_{i, t}$ & $\begin{array}{c}0.14838 * * * \\
(0.04304)\end{array}$ & $\begin{array}{c}0.09066 * * * \\
(0.02598)\end{array}$ & $\begin{array}{c}0.08737 * * * \\
(0.02466)\end{array}$ & $\begin{array}{l}-0.00789 \\
(0.03545)\end{array}$ & $\begin{array}{c}0.01099 \\
(0.04556)\end{array}$ & $\begin{array}{c}0.01333 \\
(0.03887)\end{array}$ \\
\hline$L L E V_{i, t}$ & $\begin{array}{c}0.03453 \\
(0.04666)\end{array}$ & $\begin{array}{c}0.08737 * * * \\
(0.01501)\end{array}$ & $\begin{array}{c}0.09635 * * * \\
(0.02221)\end{array}$ & $\begin{array}{c}-0.009839 \\
(0.01637)\end{array}$ & $\begin{array}{c}0.01029 \\
(0.02545)\end{array}$ & $\begin{array}{l}-0.02421 \\
(0.02837)\end{array}$ \\
\hline$E V O L_{i, t}$ & $\begin{array}{c}-0.01678^{* *} \\
(0.00825)\end{array}$ & $\begin{array}{c}-0.02546^{* * *} \\
(0.00453)\end{array}$ & $\begin{array}{c}-0.02442 * * * \\
(0.00673)\end{array}$ & $\begin{array}{c}0.01287 \\
(0.04008)\end{array}$ & $\begin{array}{c}0.01726 \\
(0.03551)\end{array}$ & $\begin{array}{c}0.00887 \\
(0.03899)\end{array}$ \\
\hline$\lambda_{i, t}$ & $\begin{array}{c}-0.12938^{* * *} \\
(0.03928)\end{array}$ & $\begin{array}{c}-0.14657 * * * \\
(0.03029)\end{array}$ & $\begin{array}{c}-0.15363 * * * \\
(0.03848)\end{array}$ & $\begin{array}{c}-0.13948 * * * \\
(0.02637)\end{array}$ & $\begin{array}{c}-0.13657 * * * \\
(0.02830)\end{array}$ & $\begin{array}{c}-0.16935^{* * *} \\
(0.03453)\end{array}$ \\
\hline CONS & $\begin{array}{l}0.014536 \\
(0.04845)\end{array}$ & $\begin{array}{c}0.02738 \\
(0.05677)\end{array}$ & & $\begin{array}{c}0.03847 * * * \\
(0.01112)\end{array}$ & $\begin{array}{c}0.03444 * * \\
(0.01717)\end{array}$ & \\
\hline Wald & 236 & 236 & 236 & 1411 & 1411 & 1411 \\
\hline $\mathrm{F}$ & 949 & 1185 & 1185 & 7055 & 8466 & 8466 \\
\hline Sargan & $172.43 * * *$ & & & $156.89 * * *$ & & \\
\hline Hansen & & $99.55 * * *$ & & & $83.37 * * *$ & \\
\hline $\mathrm{m}_{1}$ & $44.89 * * *$ & & & $35.89 * * *$ & & \\
\hline $\mathrm{m}_{2}$ & & 131.93 & & & 127.14 & \\
\hline Firms & $-6.12 * * *$ & $-6.56 * * *$ & & $-5.88 * * *$ & $-5.65 * * *$ & \\
\hline Observations & -0.28 & -0.22 & & -0.26 & -0.43 & \\
\hline
\end{tabular}

Notes: 1. Robust Standard Deviations in parenthesis. $2 . * * *$ statistically significant at $1 \%$ level; **statistically significant at 5\% level; and *statistically significant at $10 \%$ level. 3. Estimations include sector dummy variables, but estimated parameters are not presented in the tables. 4. Estimates include annual dummy variables, but estimated parameters are not presented in the tables 
Paulo MAÇÃS NUNES. Ph.D. in Economics, Associate Professor at the Department of Management and Economics to Beira Interior University and Researcher in CEFAGE-UE (Center for Advanced Studies in Management and Economics). The research interests are Applied Economics, Corporate Finance, Industrial Economics and Microeconomics. Paulo Maçãs Nunes is the author of articles in various journals: Journal of Business Economics and Management, Entrepreneurship Theory \& Practice; Research Policy; Journal of Evolutionary Economics, Small Business Economics, Industrial and Corporate Change, Journal of Business Research, Journal of Service Management, Applied Economics, Applied Economics Letters, Applied Financial Economics Letters, Economic Record, The Services Industries Journal, and other journals.

Ana VIVEIROS. Master in Economics in Beira Interior University at the Department of Management and Economics, and BPI (Banco Português de Investimento) director member.

Zélia SERRASQUEIRO. Ph.D. in Management, Associate Professor at the Department of Management and Economics to Beira Interior University and Researcher in CEFAGE-UE (Center for Advanced Studies in Management and Economics). The Research interests are Corporate Finance and Entrepreneurial Finance. Zélia Serrasqueiro is the author of articles in various journals: Journal of Business Economics and Management, Entrepreneurship Theory \& Practice; Research Policy; Journal of Evolutionary Economics; Small Business Economics; Industrial and Corporate Change, Journal of Business Research, Journal of Service Management, Applied Economics, Applied Economics Letters, Applied Financial Economics Letters, The Services Industries Journal, Social Responsibility Journal, Review of Accounting and Finance, and other journals. 